\title{
Vocal Cord Paralysis and Dysphagia Caused by Diffuse Idiopathic Skeletal Hyperostosis (DISH): Clinical and Radiographic Findings
}

\section{Diffüz İdiyopatik Iskelet Hiperostoz'un (DiSH) Neden Olduğu Vokal Kord Paralizisi ve Disfaji; Radyolojik ve Klinik Bulguları}

\author{
Ramazan BÜYÜKKAYA', Ayla BÜYÜKKAYA², Beyhan ÖZTÜRK'1, Mustafa ÖZŞAHIN³ , Beşir ERDOĞMUŞ' \\ 'Department of Radiology, Düzce University Faculty of Medicine, Düzce, Turkey \\ ${ }^{2}$ Department of Radiology, Düzce Atatürk State Hospital, Düzce, Turkey \\ ${ }^{3}$ Department of Physical Medicine and Rehabilitation, Düzce University Faculty of Medicine, Düzce, Turkey
}

\begin{abstract}
Diffuse idiopathic skeletal hyperostosis (DISH), also called Forestier disease, is usually observed in elderly people older than 60 years, and the etiology is not known exactly. This disease is usually asymptomatic but may present with different symptoms related to mechanical compression due to osteophytes. Although dysphagia is well known among the presenting symptoms of DISH, particularly vertebral dysphagia, due to osteophyte compression, vocal cord paralysis is rarely reported. In this report, a 78-year-old male presented with dysphagia and hoarseness, and as a result of the evaluation, left vocal cord paralysis due to an entrapped recurrent laryngeal nerve and esophageal compression secondary to cervical osteophytes was detected. We discuss the clinical and imaging features of this unusual case of Forestier's disease in conjunction with the literature.
\end{abstract}

Key Words: DISH, vocal cord paralysis, computed tomography, magnetic resonance imaging
Özet

Yaygın idiyopatik iskelet hiperostozu (diffuse idiopathic skeletal hyperostosis-DISH) ya da Forestier hastalığı sıklıkla 60 yaş üzeri yaşlı popülasyonda görülen ve etiyolojisi tam olarak bilinmeyen bir hastalıktır. Genellikle semptomsuz olan bu hastalık osteofitlere bağlı mekanik basının neden olduğu farklı semptomlarla prezente olabilmektedir. Semptomları arasında osteofit basısına bağlı "vertebral disfaji" olarak bilinen disfaji iyi bilinmesine rağmen oldukça nadir olarak vokal kord paralizisine de neden olabilmektedir. Yutma güçlüğü ve ses kısıklığı yakınmasıyla başvuran DiSH tanısı koyduğumuz 78 yaşındaki bir erkek olgumuzda yapılan incelemeler sonucunda servikal osteofitlerin özofagus ve sol rekürren laringeal siniri basıya uğrattığı ve sol vokal kordda paraliziye neden olduğu anlaşıımıştır. Biz de burada nadir rastlanan bu olgunun klinik ve görüntüleme bulgularını literatür eşliğinde sunmayı amaçladık.

Anahtar Kelimeler: DISH, vokal kord paralizisi, bilgisayarlı tomografi, manyetik rezonans görüntüleme

\section{Introduction}

Diffuse idiopathic skeletal hyperostosis (DISH) (also called ankylosing hyperostosis, Forestier's disease, or spondylitis ossificans ligamentosa) is an age-related chronic condition whose principal manifestation is new bone formation without degenera- tive, traumatic, or postinfection changes (1). Although DISH is usually asymptomatic, it can induce dysphagia, stridor, cough, odynophagia, otalgia, foreign body sensation, neck pain, and restriction of the mobility of the spine. Dysphagia due to esophageal compression, back pain and stiffness, and restriction of the mobility of the spine is the most common presentation of 


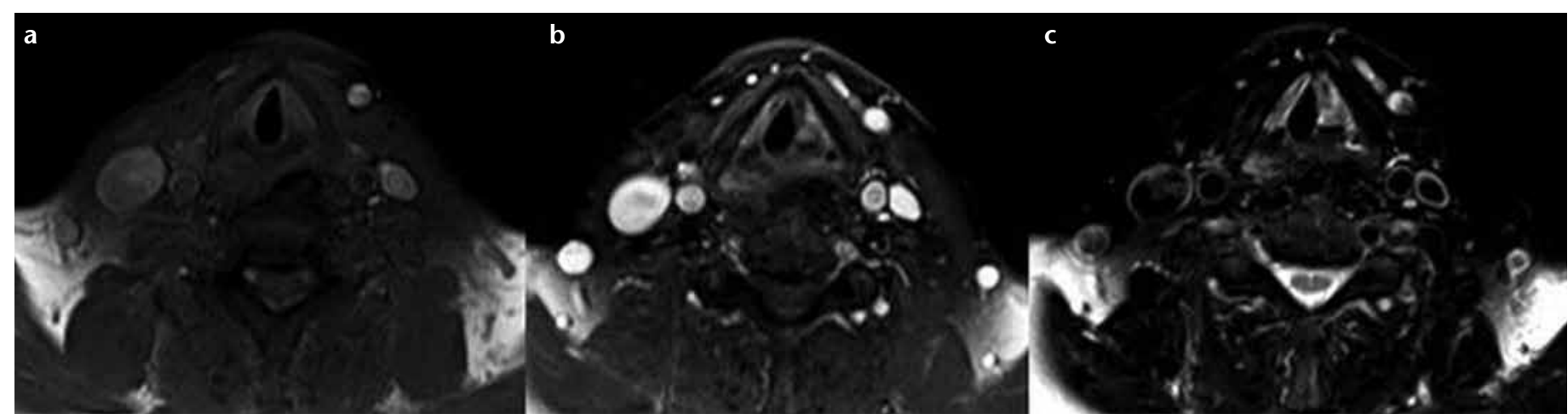

Figure 1. a-c. MRI. On the axial T1-WI, there is clear asymmetry between both vocal cords (a); T1-weighted gadolinium post-contrast MRI demonstrates no enhancement (b). T2-weighted (c) imaging

DISH (2). According to case reports in the literature, DISH of the cervical spine frequently causes dysphagia. In contrast, our patient presented with dysphagia, as well as hoarseness, which was caused by vocal fold paralysis as a result of compression of the recurrent laryngeal nerve and was confirmed by diagnostic imaging.

\section{Case Report}

A 78-year-old male presented with a history of progressively worsening dysphagia and hoarseness for a number of years. He had a history of smoking for 25 years and diabetes and hypertension that were controlled with medication. Contrast-enhanced cervical magnetic resonance imaging (MRI) at another institution showed left vocal fold thickening, and the patient was referred to our hospital for a comprehensive evaluation. Video laryngoscopy revealed a hard, protruding submucosal mass in the posterior hypopharyngeal wall, which narrowed the epiglottis-posterior hypopharyngeal wall distance. The finding of the defined mass lesion by laryngoscopy and the defined thickening of the vocal cords by MRI, together with the history of smoking, led to the patient being referred to our department for further evaluation with a suspected mass lesion. Asymmetric vocal cords were confirmed by a detailed assessment using MRI, and no pathological enhancement was observed, suggesting a mass lesion (Figure $1 \mathrm{a}-\mathrm{c}$ ). At the level of the epiglottis, the surface of the pharyngeal wall was intact, but the air column was narrowed. A detailed evaluation revealed that vertebral osteophytes compressed the left vocal fold postcricoid region and the pharyngoesophageal segment. Due to the limitations of the bone structure assessment by $\mathrm{MRI}$, radiography and computed tomography $(\mathrm{CT})$ of the cervical vertebra were planned. Multidetector CT and reformatted images confirmed the presence of bridging osteophyte formations extending from the $\mathrm{C} 3$ to C7 anterior vertebral body. Additionally, the epiglottis-posterior hypopharyngeal wall distance was narrowed, and the inferior constructor muscle and posterior cricoarytenoid muscle were compressed due to osteophytes on the left side. Because of dysphagia, barium esophagograms were obtained and showed external compression of the pharyngoesophageal segment by the large osteophytes (Figure 2a-c). Asymmetric thickening of the vocal cord on the left side, dilated left pyriform sinus and left laryngeal ventricle, and anteriomedial deviation of the arytenoid cartilage were illustrated. Radiologic imaging findings supported left vocal fold paralysis (Figure 3a, b). Laboratory tests, including sedimentation and HLA-B27 levels, were normal. These findings, together with the appearance of spinal lesions, led to the diagnosis of DISH. Anti-inflammatory drugs were used in the treatment, and symptomatic relief was observed. The patient was recommended to have clinical and radiological follow-ups.

\section{Discussion}

Anterior cervical osteophytes occur in 20\%-30\% of the elderly population and generally remain asymptomatic (3). Mosher, in 1926, was the first to report dysphagia due to cervical spine osteophytes (4). In 1948, Forestier and Rotés-Querol described vertebral ankylosing hyperostosis. Today, this entity is known as DISH. The Resnick radiographic criteria for the diagnosis of DISH include: (a) the presence of flowing ossification and calcification along the antero-lateral aspect of at least four contiguous vertebral bodies, (b) the preservation of intervertebral disk heights in the involved vertebrae, and (c) the absence of apophyseal joint bony ankylosis and sacroiliac joint erosion (5). The etiology of DISH remains obscure. The prevalence of the disease is 3 times higher in males than in females, and it is more common in individuals older than 70 years. The radiographic findings and demographic data of our case support the data in the literature on DISH.

Diffuse idiopathic skeletal hyperostosis is characterized by the presence of ossification along the anterolateral aspect of vertebral bodies $(6,7)$. The thoracic region is almost always involved (97\%). The lumbar (90\%) and cervical (78\%) regions and all three segments (70\%) are affected to a lesser extent. Although the symptoms of DISH depend on its localization, the most common manifestations are back and neck pain, stiffness, restriction of mobility of the spine, and dysphagia due to esophageal compression (2). Although large osteophytes should be considered in patients presenting with progressive dysphagia, the differential diagnosis of dysphagia includes esophageal and mediastinal tumors, esophagitis, esophageal stricture, motility disorders, neuromuscular disorders, spinal cord tumors, and aberrant vascular formations (6-8). In our case, exclusion of the diseases in the differential diagnosis through a detailed clinical 


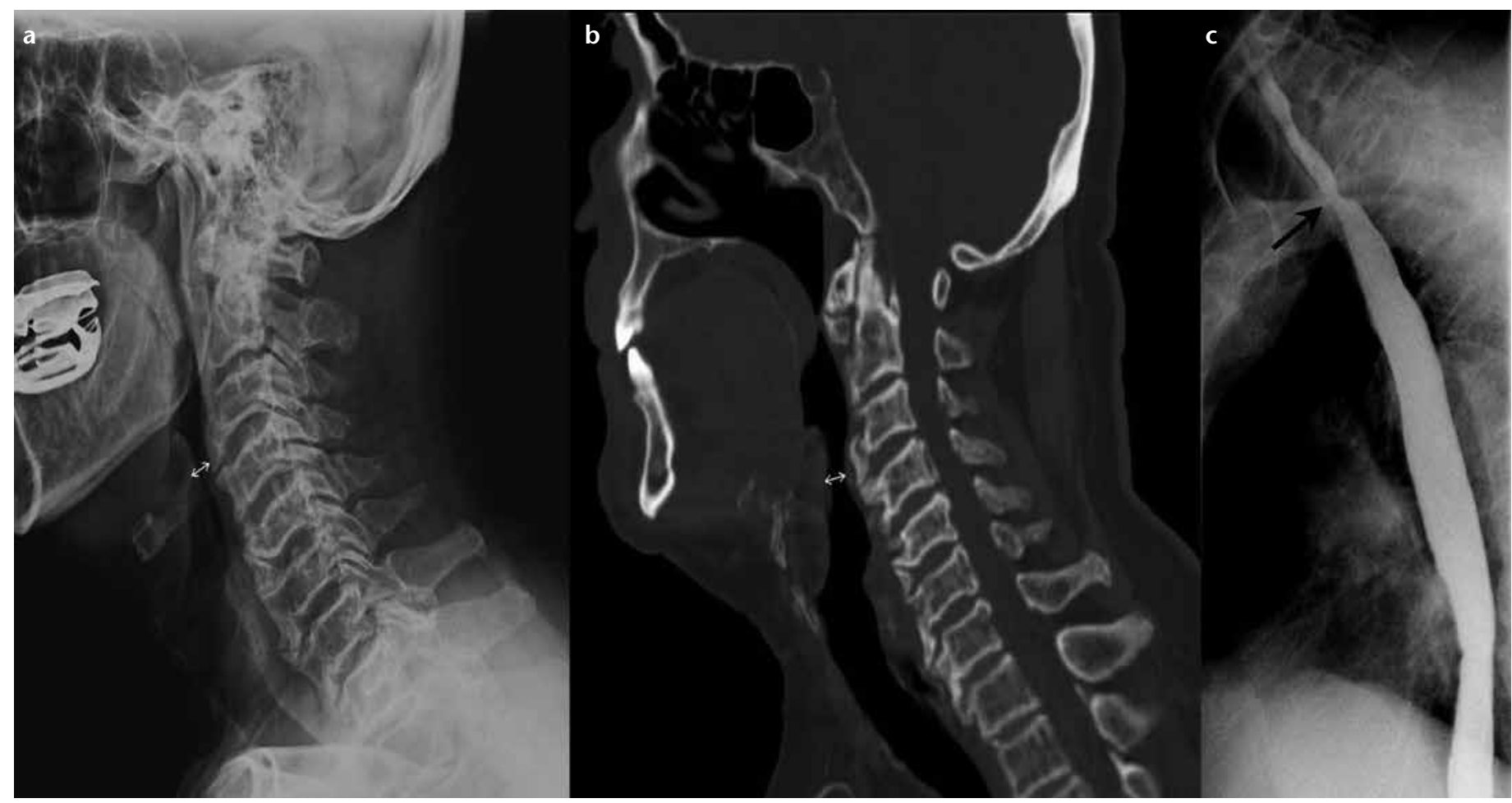

Figure 2. a-c. The epiglottis-posterior hypopharyngeal wall distance was narrowed $(a, b)$. Barium esophagograms show external compression of the pharyngoesophageal segment by large osteophytes (c)

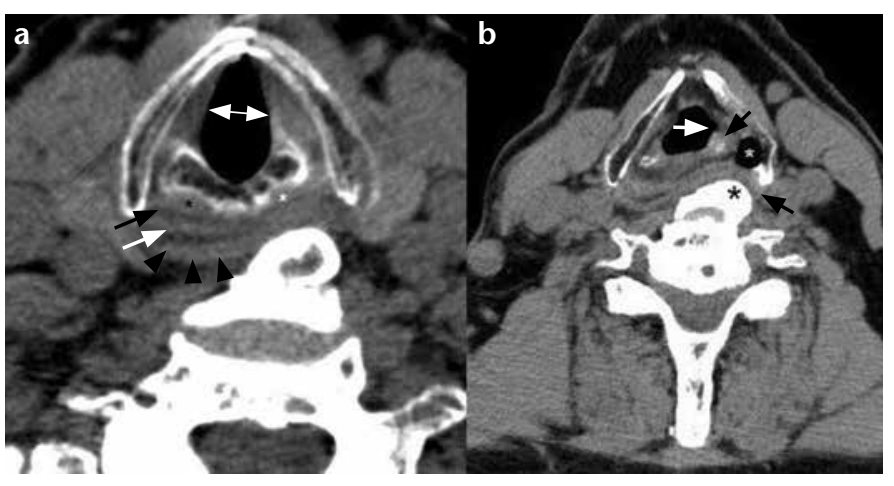

Figure 3. a, b. A 78-year-old male with characteristic computed tomography (CT) findings of vocal fold palsy. (a) An axial CT scan in the patient with left vocal fold paralysis (double arrow) shows atrophy of the left posterior cricoarytenoid (PCA) muscle (white star), a normal right PCA muscle (black star), the laryngeal pharynx (white arrow), fat (black arrow), and the inferior constrictor muscle (arrowhead). (b) The left laryngeal ventricle (white arrow), thickening and medial positioning of the left aryepiglottic fold (black arrow), and dilatation of the right pyriform sinus (white star). An axial CT scan demonstrates cervical osteophytes (black star) compressing the post-cricoid larynx. Note the severe narrowing of the spaces behind the inferior cornu of the thyroid cartilage (curved arrow)

evaluation with video laryngoscopy and imaging modalities, such as radiography, esophagography, CT, and MRI, confirmed that the reason of the dysphagia was osteophytes.
Dysphonia, a less common symptom, may occur due to direct compression of osteophytes to the postcricoid region and recurrent laryngeal nerve, resulting in fixation of the arytenoids (4). While there is no work in the literature regarding the prevalence of dysphonia, there are only few case reports. Aydin et al. (9) reported a case of bilateral vocal cord paralysis due to compression of the bilateral postcricoid region associated with cervical osteophytes, which required emergency intervention. Hassard reported two cases with bilateral vocal fold paralysis and a postcricoid ulcer due to the mechanical effects of osteophytes and accompanying clinical signs of infection (10). In our case, the patient did not need immediate intervention; however, potential life-threatening airway obstruction can occur if the diagnosis is late. Compression was localized to the left postcricoid region, and there was no sign of infection or ulceration in our patient. The symptoms of our patient was neither as emergency as the first case, nor as chronic as the second one. There are a variety of clinical presentations in patients with DISH. In these cases, symptoms are usually due to compression of adjacent structures. The main reasons of the clinical variety in presentation are differences in the compressed structure and duration and intensity of the compression.

Common issues in DISH cases are narrowing of the air column and false anticipation of the mass lesion by the clinician. Vertebral osteophytes may be insufficient by MRI imaging, so we believe that multidetector $\mathrm{CT}$ imaging is necessary. 


\section{Conclusion}

We must be aware of anterior cervical osteophytes as a common but rarely symptomatic finding in the geriatric population. DISH may induce varying degrees of symptoms, especially dysphagia, but the diagnosis should not be corrected without the exclusion of diseases in the differential diagnosis with appropriate imaging techniques. Although it is rare, vocal fold paralysis, as in our case, due to an entrapped recurrent laryngeal nerve secondary to DISH should be kept in mind. Awareness of the relevant radiological findings and recognition of hypertrophic osteophytes using appropriate imaging modalities are important, because these symptoms can progress rapidly and lead to life-threatening respiratory obstruction.

Informed Consent: Written informed consent was obtained patient who participated in this case.

Peer-review: Externally peer-reviewed.

Author Contributions: Concept - R.B.; Design - R.B., A.B.; Supervision - B.E., M.Ö.; Funding - R.B., A.B.; Materials - R.B., M.Ö.; Data Collection and/or Processing - B.Ö.; Analysis and/or Interpretation - B.E., R.B., M.Ö.; Literature Review - B.Ö., A.B., R.B.; Writer - R.B., A.B.; Critical Review R.B., A.B., B.E., M.Ö.; Other - M.Ö., A.B., B.E., B.Ö.

Conflict of Interest: No conflict of interest was declared by the authors.

Fnancial Disclosure: The authors declared that this study has received no financial support.

Hasta Onamı: Yazılı hasta onamı bu olguya katılan hastadan alınmıştır.

Hakem değerlendirmesi: Dış bağımsız.

Yazar Katkıları: Fikir - R.B.; Tasarım - R.B., A.B.; Denetleme - B.E., M.Ö.; Kaynaklar - R.B., A.B.; Malzemeler - R.B., M.Ö.; Veri toplanması ve/veya işlemesi - B.Ö.; Analiz ve/veya yorum - B.E., R.B., M.Ö.; Literatür taraması - B.Ö., A.B., R.B.; Yazıyı yazan - R.B., A.B.; Eleştirel Inceleme - R.B., A.B., B.E., M.Ö.; Diğer - M.Ö., A.B., B.E., B.Ö.

Çıkar Çatışması: Yazarlar çıkar çatışması bildirmemişlerdir.

Finansal Destek: Yazarlar bu çalışma için finansal destek almadıklarını beyan etmişlerdir.

\section{References}

1. Çağavi F, Kalaycı M, Uğur MB, Uzun L, Asil K, Açıkgöz B. Dysphagia and diffuse idiopathic skeletal hyperostosis: Case report. Türk Nöroşirurji Dergisi 2004;14:146-50.

2. Cammisa M, De Serio A, Guglielmi G. Diffuse idiopatic skeletal hyperostosis. Eur J Radiol 1997;27:7-11. [CrossRef]

3. Kissel P, Youmans JR. Posttraumatic anterior cervical osteophyte and dysphagia: Surgical report and literature review. J Spinal Disord 1992;5:104-7. [CrossRef]

4. Khtar S, O'Flynn PE, Kelly A, Valentine PM. The management of dysphasia in skeletal hyperostosis. J Laryngol Otol 2000;2:154-7.

5. Resnick D, Niwayama G. Radiographic and pathologic features of spinal involvement in diffuse idiopathic skeletal hyperostosis (DISH). Radiology 1976;119:559-68. [CrossRef]

6. Buyukkaya A, Buyukkaya R, Ozaydın I, Yazgan Ö, Yazgan S. Rarely cause of disphagia: Aberrant Insertion of the right subclavian artery. Konuralp Tıp Dergisi 2009;1:22-4.

7. Burgess C, Hughes R, Griffiths S, Cadoux-Hudson T. A decade of unexplained dysphagia. Ear Nose Throat | 2009;6:958-60.

8. Ladenhemn SE, Marlowe FI. Dysphagia secondary to cervical osteophytes. Am J Otolaryngol 1999;20:184-9. [CrossRef]

9. Aydin K, Ulug T, Simsek T. Case report: bilateral vocal cord paralysis caused by cervical spinal osteophytes. Br J Radiol 2002;75:990-3. [CrossRef]

10. Hassard AD. Cervical ankylosing hyperostosis and airway obstruction. Laryngoscope 1984;94:966-8. [CrossRef] 